\title{
Novi svjetski geopolitički poredak: teorijske odrednice
}

\author{
Petar Kurečić
}

\begin{abstract}
Dekonstrukcija geopolitičkog poretka hladnog rata, praćena geopolitičkom tranzicijom, donijela je uspostavu novog svjetskog geopolitičkog poretka. Kako bi shvatili prirodu i značajke suvremenog, novog svjetskog geopolitičkog poretka, moramo se upoznati s određenjima svjetskog poretka općenito, uvjetima nastanka, akterima i procesima novog svjetskog geopolitičkog poretka. Akteri presudno oblikuju poredak, te snažno utječu na procese. Države kao najvažniji akteri poretka doživljavaju značajnu transformaciju. Na procese najviše utječu međunarodne organizacije, a ne države. Međutim, procesi se nekad odvijaju gotovo samostalno. Akteri i procesi međudjelovanjem stvaraju globalne geopolitičke odnose. Budućnost svjetskog poretka neizvjesna je. Bit će to budućnost puna rizika, neizvjesnosti i nesigurnosti.
\end{abstract}

Ključne riječi: geopolitički poredak, međunarodni poredak, novi svjetski geopolitički poredak, akteri svjetskog poretka, procesi u svjetskom poretku, globalni geopolitički odnosi.

\section{New World Geopolitical Order: Theoretical Determinants}

Deconstruction of the Cold War geopolitical order, accompanied by geopolitical transition, has brought the establishment of a New World geopolitical order. To comprehend the nature and characteristics of that new order, we must be generally acquainted with the world order features, with the conditions of its emergence, players and processes. Players form the order crucially, and powerfully influence the processes. States, as the most important order players, experience a significant transformation. The processes are mostly influenced by international organisations, not states. However, sometimes they almost independently. The players and processes create global geopolitical relations by interaction. The future of the world order is doubtful. It will be full of risks, insecurity and uncertainty.

Key words: new geopolitical world order, players in world order, processes in world order, global geopolitical relations

\section{UVOD}

Tema ovog rada je novi svjetski geopolitički poredak. Poredak koji je nastao u posthladnoratovskom razdoblju, danas je još uvijek u fazi svog nastanka i sazrijevanja, u kojoj prolazi neprekidne transformacije. Ove transformacije nisu fundamentalne u smislu potpunih promjena okoline u kojoj poredak opstoji i razvija se. Millieu ili okolinu čini globalni geopolitički sustav, koji istražuje geopolitika. Geopolitika je dio političke znano- 
sti i kontaktno područje prema geografskoj znanosti zbog prirode objekta koji proučava. Geopolitika je studij odnosa geografskog prostora i politike. Primarni objekt njezina proučavanja je odnos između prostora, moći i stanovništva. Geopolitika poredak istražuje kroz specifičan framework. Akteri geopolitičkog poretka i procesi u poretku ostali su gotovo jednaki i nakon posljednje geopolitičke tranzicije, kojom je uspostavljen novi svjetski geopolitički poredak. Promijenili su se položaj i moć aktera poretka, te intenzitet i karakter procesa koji u njemu vladaju. Kumulativnim djelovanjem aktera i procesa promijenili su se i globalni geopolitički odnosi. Oni su postali neizvjesniji, s većim brojem značajnih aktera. Imamo priliku istraživati promijenjene okolnosti i izvoditi nove zaključke, kako bi bili spremni odgovoriti na izazove suvremenog doba. U radu su izložena poimanja geopolitičkog poretka i prijelaza iz jednog poretka u drugi, uvjeti nastanka novog svjetskog geopolitičkog poretka, te značajke aktera i procesa u tom novom poretku.

\section{GEOPOLITIČKI POREDAK}

Sama riječ poredak po svom značenju implicira postojanje određenog stupnja reda, hijerarhije i organizacije (koje nema bez hijerarhije). Geopolitički poredak odnosi se na hijerarhijsku organizaciju prostora koja vlada u geopolitičkom sustavu. Ključna odrednica geopolitičkog poretka nije hijerarhija, nego anarhija i međuovisnost aktera. Ako posebno ne označimo da se radi o regionalnom poretku, smatramo da se radi o globalnom geopolitičkom poretku. Potreba istraživanja globalnog geopolitičkog poretka nesumnjiva je. Zahtijeva globalni ili svjetski pristup, koji u obzir uzima faktore globalnog značenja i dosega, te svijet smatra jedinstvenom cjelinom, a ne skupom izdvojenih cjelina koje predstavljaju države. Usprkos rascjepkanosti i fragmentiranosti političkih jedinica, utjecaji faktora sve su više globalni. Prodiru kroz barijere i djeluju na velikim udaljenostima. Posljedica je to znanstveno-tehničke revolucije, najviše izražene u području komunikacijskih i informatičkih tehnologija, te procesa globalizacije, koji je sve prisutniji i brži.

Geopolitički poredak je geopolitička kategorija koja se može definirati kao geografski aspekt pravila, institucija, aktivnosti i strategija kroz koje funkcionira međunarodna politička ekonomija u pojedinim povijesnim razdobljima. Može se definirati i kao poredak u sustavu suverenih teritorijalnih država, koji je nastao nakon Westphalskog mira 1648. g. Taylor (1993.) poredak definira kao danu raspodjelu moći u svijetu, po kojoj se ravna i u skladu s kojom djeluje većina političkih elita u svijetu. Geopolitički poredak je prevladavajuće stanje geopolitičkih odnosa u nekom povijesnom razdoblju. Ujedno je i koncept kojim se objašnjavaju geopolitički odnosi koji tvore neki poredak u određenom razdoblju povijesti. Geopolitički poredak čine elementi i faktori koji su dio geopolitičke problematike, te su geografski i geopolitički relevantni. Stoga kad geopolitika istražuje svjetski poredak, istražuje poredak u globalnom geopolitičkom sustavu. Geopolitika, kao znanstvena disciplina političke znanosti i kontaktno područje prema geografskoj znanosti koristi geopolitički pristup u analizi geopolitičkih odnosa. Geopolitiku zanima geografska komponenta i geografski faktori. U obzir uzima prostorne odnose koji značajno utječu na odnose moći jer odnosi moći postoje u prostoru.

Ovdje je potrebno ukratko prikazati dva viđenja koja se odnose na prirodu i značajke geopolitičkog poretka općenito. Autor prvog poimanja je $P$. J. Taylor, a autori drugog 
poimanja su J. Agnew i S. Corbridge. Taylor za objašnjavanje geopolitičkog poretka smatra ključnim pojam ciklus hegemonije, koji je oznaka za razdoblje u povijesti geopolitičkih odnosa u kojem je ostvarena prevlast ili hegemonija jedne države nad drugima. Hegemoniju ne smatra a priori negativnom, a postojanje visokog stupnja hegemonije smatra ključnim za nastanak globalnog geopolitičkog poretka. U povijesti su dosad postojala dva ciklusa hegemonije, britanski i američki. Britanski ciklus počeo je padom Napoleona Bonaparte i trajao je do kraja 19. stoljeća, kad ga počinje zamjenjivati američki ciklus koji po nekima traje i danas. Po nekima treba razlikovati prvi i drugi ciklus američke hegemonije. Prvi ciklus završio je s krajem hladnog rata. Zatim je počeo ciklus nove hegemonije koji je donio novi svjetski geopolitički poredak, koji se opet uglavnom oblikuje pod utjecajem SAD-a. Geopolitički poredak Taylor poima kao koncept kojim se u geopolitici objašnjava složenost odnosa koji vladaju u međunarodnom sustavu. Geopolitički poredak smatra razdobljem u kojem umjesto međunarodne anarhije prevladava vladavina velikih sila koje vrše akomodaciju svojih interesa. Također kaže da je geopolitički poredak skup geopolitičkih kodova u kojima je u velikoj mjeri prisutna jedna jedinstvena matrica, koja utječe na njih kao izraz jedinstvenog geopolitičkog poretka. Geopolitički kod rezultat je praktičnog geopolitičkog zaključivanja. Sadrži skup političko-geografskih pretpostavki koje podupiru vanjsku politiku države. Obuhvaća definiciju nacionalnih interesa, identifikaciju vanjskih prijetnji tim interesima, planirani odgovor na prijetnje i opravdanje tog odgovora. Geopolitičkih kodova ima koliko ima i država u svijetu, a kodovi najjačih država imaju utjecaj ne samo na susjedne države, nego na države u regiji, na kontinentu ili u cijelom svijetu ako je država dovoljno snažna (Taylor 1993).

Koncept geopolitičkog poretka Agnewa i Corbridgea koncept je koji je izrastao iz škole kritičke geopolitike. Koncept se zasniva na mnogo širem poimanju geopolitičkog poretka i na istraživanjima Lefebvrea, koji pravi analitičko razlikovanje između prostorne prakse (spatial practice), predstavljanja prostora (representation of space) i predstavljenog prostora (representational space). Prostorna praksa odnosi se na materijalne i fizičke tokove, interakcije i komunikacije koje se dešavaju u prostoru kao glavna obilježja ekonomske proizvodnje i socijalne reprodukcije. Predstavljanje prostora uključuje sve koncepte, praksu i geografske kodove koji koriste za objašnjavanje prostorne prakse. Predstavljeni prostori mogući su scenariji prostorne prakse ili "zamišljene geografije”, koje nadahnjuju promjene u predstavljanju prostora, s ciljem transformacije prostorne prakse. Na temelju ovog razlikovanja napravljeno je razlikovanje geopolitičkog poretka i geopolitičkog diskursa. Geopolitički poredak odnosi se na političku ekonomiju prostorne prakse ili hijerarhijsku organizaciju prostora. Geopolitički diskurs odnosi se na geopolitičku zamisao hijerarhijske organizacije prostora, koja u svom središtu ima interpretaciju tog prostora, koja ne mora nužno biti ispravna i ne mora se ostvariti. Geopolitički diskurs odnosi se na to kako geografski aspekti globalne političke ekonomije opisuju i čitaju u vanjskopolitičkoj i ekonomskoj praksi aktera u različitim razdobljima određenog geopolitičkog poretka. Geopolitički diskurs uključuje aplikaciju predstavljanja prostora koja usmjerava prostornu praksu karakterističnu za neki geopolitički poredak (Agnew, Corbridge 1995). Određeni geopolitički poredak, pa tako i novi svjetski geopolitički poredak, zapravo je predstavljeni prostor. Razlikovanje između prostorne prakse i predstavljanja prostora, geopolitičkog poretka i geopolitičkog diskursa, predstavlja veliki napredak u poimanju i istraživanju u geopolitici. 
Kritička geopolitika geopolitički poredak definira kao skup uobičajenih pravila, institucija, aktivnosti i strategija kroz koje je djelovala i djeluje međunarodna politička ekonomija u pojedinim razdobljima povijesti. Atribut geopolitički ukazuje na geografske elemente svjetskog poretka. Svaki svjetski geopolitički poredak mješavina je kohezije i sukoba između aktera, te je nemoguće postići poredak bez ikakvih sukoba. Da bi poredak uopće postojao, mora postojati global governance - definiranje aktera, pravila djelovanja, principa interakcije i široko prihvaćenih pretpostavki koje se tiču trgovine, vojne moći i diplomacije. Ovo uključuje međunarodne organizacije i režime koji se odnose na djelovanje država na određenim područjima (novčani tokovi, trgovina, sigurnost). Svjetski poredak uključuje i subjektivne pretpostavke koje dijele najvažniji akteri svjetskog poretka. Agnew i Corbridge hegemoniju doživljavaju ne kao hegemoniju nekog hegemona nego kao hegemoniju uobičajenih pravila i ideoloških predodžbi koje poretku daju "normalnost" i "racionalnu prihvatljivost" svim akterima. Ovakva hegemonija postoji otkad postoji poredak, jer je postojanje geopolitičkog poretka nemoguće bez određenog stupnja gotovo općeprihvaćenih pravila, djelovanja i institucija bez kojih poredak ne bi bio uspostavljen i ne bi mogao djelovati. Hegemonija dakle može postojati bez postojanja hegemona (Agnew, Corbridge 1995).

Ova dva koncepta pokazuju nam različitost poimanja geopolitičkog poretka različitih autora. Taylorov koncept više je orijentiran na tradicionalno shvaćanje hegemonije (hegemonija hegemona) i poretka. Koncept Agnewa i Corbridgea je moderniji, uvažuje ekonomsku komponentu i poredak povezuje s djelovanje globalne političke ekonomije. Hegemoniju doživljava kao hegemoniju pravila.

Prijelaz iz jednog geopolitičkog poretka u drugi događa se u procesu koji se naziva geopolitička tranzicija. Potrebno je da se stvore povoljni uvjeti u sustavu, tj. da geopolitički poredak doživi krizu i da počne brza geopolitička tranzicija. Potrebne su snažne promjene globalnih geopolitičkih odnosa, koje su se u 20. stoljeću događale mnogo brže nego prije u povijesti. Posljednje dvije geopolitičke tranzicije su dakako ona koja je trajala od 1945 . do 1947. g., kad se desio prijelaz u geopolitički poredak hladnog rata, te ova posljednja koja je trajala od 1989. do 1991. g., kad se desio prijelaz iz hladnoratovskog geopolitičkog poretka u novi svjetski geopolitički poredak. Geopolitička tranzicija promijenila je karakter i značenje struktura i procesa u međunarodnom sustavu. Nastao je novi poredak u svijetu, kao posljedica značajnih promjena u geopolitičkim odnosima, koje narušavaju geopolitički poredak, tj. stanje geopolitičkih odnosa u nekom razdoblju povijesti. Posljednja geopolitička tranzicija značajna je najviše zbog svoje iznenadne pojave i brzine kojom se desila. Bila je rezultat kraja hladnog rata, specifičnog pojavnog oblika bipolarnih međunarodnih odnosa. ${ }^{1}$ Jedan pol (SSSR sa satelitima) se urušio iznenadno i velikom brzinom i ostavio drugi pol kao najveći centar moći u svijetu (SAD) bez pravog suparnika. Ovo je ključan moment za određenje novog svjetskog geopolitičkog poretka.

\section{UVJETI RAZVOJA NOVOG SVJETSKOG GEOPOLITIČKOG PORETKA}

Suvremeni svjetski geopolitički poredak razvija se u specifičnim uvjetima novih, postmodernih geopolitičkih odnosa u svijetu, koji se značajno razlikuju od uvjeta koji su vladali u prethodnom geopolitičkom poretku hladnog rata. Novi svjetski geopolitički 
poredak razvija se u novom, globalnom dobu, u kojem je do izražaja došao kumulativni učinak djelovanja posthladnoratovskih odnosa u svijetu i procesa globalizacije. Globalno doba nastaje u trenutku kad ljudska društva imaju kolektivnu svijest o promjeni odnosa između prostora, vremena i sebe samih. Ono povezuje svijet bez granica koji nastaje globalizacijom i mondijalizacijom sa svijetom bez referetnih točaka i odnosa koji nastaje nakon svršetka hladnog rata. Globalno doba može se definirati kao trenutak u kojem se geopolitičke i kulturne posljedice posthladnoratovskog razdoblja povezuju s ubrzanjem procesa ekonomske, socijalne i kulturne globalizacije (Laidi 2000).

Veza ova dva momenta omogućuje promjene na svim poljima, pa stoga uvjete razvoja novog svjetskog geopolitičkog poretka sagledavamo na nekoliko osnovnih polja na kojima se razvija svijet. To su političko, vojno-sigurnosno, ekonomsko, društveno i znanstveno-tehnološko polje.

Uvjeti u kojima se razvija novi svjetski geopolitički poredak su:

\section{A) Na političkom polju:}

1. Broj članica globalnog sustava povećao se za preko 20 država - posljedica je to najveće proliferacije država nakon dekolonizacije i ulaska u međunarodni sustav;

2. Nastanak sve većeg broja aktera geopolitičkog poretka, uz države se pojavljuju različite organizacije i integracije, nevladine organizacije, skupine ljudi i pokreti;

3. Kriza nacionalne države koja se kao proizvod prošlosti sa svim svojim ograničenjima sve teže prilagođuje suvremenim uvjetima koji vladaju unutar i van njenih granica. Nacionalna država sve teže zadovoljava potrebe skupina društva koje egzistiraju unutar njenih granica, a u geopolitičkim odnosima ima konkurenciju ostalih aktera geopolitičkog poretka;

4. Ograničavanje suvereniteta države pomoću djelovanja međunarodnih instrumenata moći (vojno-politički savezi i međunarodne organizacije);

5. Slabljenje nekih svjetskih centara moći i jačanje drugih što dovodi do novih odnosa;

6. Novi val demokratizacije u Istočnoj Europi, Aziji i donekle u Africi;

7. Široko prihvaćanje liberalne demokracije kao jedinog mogućeg puta u budućnost kod većine uspješnih društva koja su gospodarski razvila ili se žele razviti (Fukuyama 1994);

8. Pojava zemalja u tranziciji i zemalja "otpadnika" izvan svjetskog poretka;

9. Jačanje regionalnih geopolitičkih poredaka uslijed slabljenja bipolarnosti;

10. Pretvorba SAD-a u jedinu svjetsku supersila i globalnog lidera (ili hegemona?) sa svim ovlaštenjima i odgovornostima koje donosi globalno vodstvo; ${ }^{2}$

11. Raspad jedne svjetske supersile, SSSR-a i pretvorba većine država sljednica u golem prostor nestabilnosti opterećen tranzicijskim problemima. Bio je to definitivan kraj komunističkog kontinentalnog bloka;

12. Stvaranje novih podjela nakon što je izbrisana hladnoratovska bipolarna podjela;

13. Pojava opozicije novom svjetskom poretku u državama na svim kontinentima;

14. Nemogućnost rješavanja središnjih pitanja opstanka i razvoja svijeta. 


\section{B) Na vojno-sigurnosnom polju:}

1. Odsutnost mogućnosti globalnog sukobljavanja nuklearnim oružjem;

2. Postojanje svjetske supersile koja na vojnom polju nema dostojnog suparnika;

3. Redefiniranje nacionalnih sigurnosnih i strategijskih ciljeva i interesa gotovo svih država u svijetu, posebice najjačih i najviše uključenih u svjetski poredak;

4. Pojava novih izazova sigurnosti s bitno drugačijim značajkama. Novi izazovi dijele se u tri skupine: latentni tradicionalni konflikti koji sada ulaze u novu fazu trajanja na višoj razini, novonastali konflikti i krizna žarišta vezani uz velike promjene u geopolitičkim odnosima u geopolitičkoj tranziciji, globalni izazovi sigurnosti neteritorijalnog karaktera (terorizam, proliferacija oružja masovnog uništenja, trgovina drogom i ljudima, ekološke katastrofe itd.);

5. Sve jače globalno zagrijavanje i zagađivanje, koje je sve veća prijetnja;

6. Pojava svijesti o potrebi stvaranja sustava kolektivne sigurnosti na regionalnim razinama (regionalni sigurnosni režimi) i po mogućnosti na globalnoj razini.

\section{C) Na ekonomskom polju:}

1. Prijelaz razvijenog svijeta iz industrijskog u postindustrijsko doba;

2. Slabljenje zapreka i povećanje opsega međunarodne trgovine;

3. Razvoj međunarodnih ekonomskih organizacija i integracija;

4. Ubrzanje procesa globalizacije kao skupa najviše ekonomskih promjena;

5. Podjela svijeta na trgovinske blokove, međusobno konkurentne; feriju;

6. Daljnji razvoj svjetskog sistema i podjela svijeta na jezgru, poluperiferiju i peri-

7. Ubrzano pomicanje nekih dijelova svijeta iz poluperiferije u jezgru ili periferiju;

8. Izrazita nejednakost u raspodjeli svjetskih resursa i bogatstva;

9. Povećanje razlike u bogatstvu i standardu življenja između razvijenih i nerazvijenih zemalja, te između bogatih i siromašnih skupina stanovništva u zemljama;

10. Povećanje zaduženosti nerazvijenih zemalja prema razvijenim zemljama;

11. Pojava geoekonomije kao obrasca za djelovanje razvijenih država u njihovoj politici prema svijetu. Glavni protagonist geoekonomije su SAD, posebno Clintonova administracija. Geoekonomija kao obrazac djelovanja i posthladnoratovska paradigma sve više zamjenjuje geopolitiku i geostrategiju; ${ }^{3}$

\section{D) Na društvenom polju:}

1. Ubrzana transformacija društava razvijenih zemalja iz modernih u postmoderna;

2. Zaoštravanje civilizacijskih razlika u svijetu i pojava suparnika zapadne civilizacije;

3. Daljnja urbanizacija slabije razvijenih zemalja, suburbanizacija i metropolitanizacija razvijenih zemalja što dovodi do sve većih socijalnih razlika;

4. Slabljenje državne kontrole nad nekim aspektima društvenog života;

5. Ubrzani razvoj civilnog društva u demokratskim zemljama svijeta;

6. Jačanje instituta ljudskih prava u međunarodnom društvu i u sve više država; 


\section{E) Na znanstveno-tehnološkom polju:}

1. Ubrzan razvoj sredstava komuniciranja, prvenstveno telekomunikacijskih sredstava, koja omogućuju spajanje svijeta u jedinstvenu cjelinu u realnom vremenu;

2. Ubrzan razvoj informatičkih sredstava koja omogućuju prikupljanje, spremanje i obradu vrlo velikih količina podataka u kratkom vremenu;

3. Promjene u organizaciji rada uzrokovane razvojem tehnologije i organizacije rada;

4. Razvoj novih metoda znanstvenih istraživanja, posebice u prirodnim znanostima;

5. Razvoj novih prirodnih znanosti, npr. biotehnologije i moderne genetike.

\section{AKTERI NOVOG SVJETSKOG GEOPOLITIČKOG PORETKA}

Aktere novog svjetskog geopolitičkog poretka možemo nazvati i strukturama. Njihov utjecaj na poredak presudan je. Aktere geopolitičkog poretka možemo istraživati i kao subjekte međunarodnih odnosa i pritom koristiti razvijenu metodologiju međunarodnih odnosa. Svi subjekti međunarodnih odnosa nisu akteri geopolitičkog poretka, a uloga i značenje u međunarodnim odnosima različiti su im od uloge i značenja u geopolitičkom poretku. S uspostavom i razvojem svakog novog geopolitičkog poretka u svijetu dolazi do promjena koje se tiču samog poretka. Značenje nekih aktera se povećava, a nekih drugih smanjuje. Na jačanje i slabljenje pojedinih aktera utječu različiti faktori, od geografskih, preko političkih i vojnih do ekonomskih i tehnoloških. U posthladnoratovskom razdoblju akteri poretka doživljuju velike promjene svojih značajki. Sve aktere možemo podijeliti na četiri skupine. To su države, ostale teritorijalno-političke jedinice, međunarodne organizacije, ostali akteri.

Države su danas samo jedan od aktera u globalnom geopolitičkom poretku. Danas se uloga država značajno mijenja. Države još uvijek ostaju najznačajniji akteri geopolitičkog poretka, ali se njihova važnost smanjuje i uloga mijenja. Država se obično definira kao geografski ograničen entitet kojim upravlja središnja vlast, koja ima sposobnost donošenja zakona, pravila i odluka, te mogućnost njihove primjene unutar svojih granica. Država je legalni entitet priznat međunarodnim pravom kao temeljna odgovorna jedinica međunarodnog pravnog sustava. Moderna država točno je ograničen dio prostora koji ima ove atribute: državni teritorij, stalno stanovništvo, politička organizacija ili vlast, organiziranu ekonomiju, prometni sustav. Uz geografske, postoje i politički atributi države, a to su suverenitet i međunarodno priznanje. Uloga suvremenih država u novom svjetskom geopolitičkom poretku, drugačija je od uloge država u prijašnjim poretcima. Osnovno obilježje političke organizacije svijeta, podjela na suverene teritorijalne države, i dalje je prisutna. Međutim, jačaju procesi koji djeluju na države.

Identitet i interesi država i ostalih aktera poretka stvaraju se kroz interakciju jednih s drugima. Država ne može postojati ako nije priznata od ostalih država. Međuovisnost je glavna značajka geopolitičkog sustava, koji se nekad u potpunosti izjednačavao sa sustavom država, no danas je to sve manje samo sustav suverenih teritorijalnih država. Današnji sustav ima preko 190 država, što je posljedica velike proliferacije država u 20. stoljeću, 
u nekoliko valova. Geopolitički odnosi danas su najopsežniji i najdinamičniji u povijesti, s tendencijom porasta broja aktera, promjene uloge aktera, promjene strukture sustava, pojave novih i akceleracije postojećih procesa. Države postoje u prostoru i u globalnom geopolitičkom sustavu koji je anarhične prirode, jer u njemu ne postoji središnja politička vlast. Država je sposobna neke aspekte djelovanja projicirati izvan svog teritorija. Vanjskopolitičko djelovanje država djelatnost je usmjerena na postizanje promjena u sustavu. Glavni su zadatak djelovanja države nacionalni interesi i njihova zaštita.

Suverene države i međunarodna anarhija međusobno su ovisni, jer jedno djeluje na drugo oblikujući ga. Anarhija u sustavu uspostavila je odnose kompeticije u kojima se igraju igre u kojima profitiraju sposobniji, a kad je u pitanju opstanak država, uglavnom preživljavaju samo najveći i najsposobniji. Postavljaju se i neke dvojbe kad se radi o sustavu. Realizam pažnju posvećuje prirodi država koje smatra ključnima za odnose u svijetu. Neorealizam težište stavlja na sam sustav i njegove značajke, zanemarujući unutarnje političke značajke država. Pitanje je da li sustav možemo zvati sustav (zbog anarhije i nejedinstva), ili međunarodno društvo. Društvo je povijesni odgovor na postojanje sustava. Ako jedinice sustava priznaju trajnost i važnost međuovisnosti mogu stvarati pravila za izbjegavanje sukoba i postizanje promjena. Bitan aspekt djelovanja države u sustavu je upotreba sile. Borba za moć je po realistima prvorazredan cilj vanjske i unutarnje politike država. Pojmom sile najviše se bavio Hans Morgenthau, pripadnik realističke škole međunarodnih odnosa, koja je ukupnost međunarodnih odnosa izjednačila s politikom sile. Realistička škola najviše se razvila u SAD-u, u razdoblju čvrstog bipolarizma 40-ih i 50-ih godina 20. stoljeća (Vukadinović 1998). Zamah realizma vidljiv je u velikom broju teoretičara koji su oblikovali diskurse koji su utjecali na političke elite vodećih država Zapada tokom hladnog rata. Realistička škola doživjela je kritiku neorealističke škole, čiji je glavni predstavnik Kenneth $N$. Waltz. Neorealizam u središte istraživanja ne stavlja državu, nego strukturu međunarodnog sustava država, u kojem vlada stanje kooperacije ili stanje konfrontacije. Waltz je istraživao strukture međunarodnih odnosa, neovisno o unutarnjem karakteru država. Struktura međunarodnog sustava po Waltzu ima tri značajke: stanje anarhije, sve države obavljaju jednake funkcije i ravnopravne su, raspodjela sposobnosti i resursa između država nejednaka je. Kao središnji mehanizam djelovanja međunarodnog sustava Waltz navodi ravnotežu snaga. Koncepcija međunarodnog sustava počiva na snažnoj teritorijalnoj državi. Zbog teritorijalnog karaktera države koji je gotovo nepromjenjiv, međunarodne odnose treba istraživati samo na razini sustava. Objekt istraživanja je anarhija izvan državnih granica. ${ }^{4}$

U suvremenim posthladnoratovskkim uvjetima, s ubrzanjem tehnološkog napretka i procesa globalizacije dolazi do promjena unutar država kao odgovor na promjene u sustavu. Stoga i stare paradigme dolaze u krizu. Kritička geopolitika Waltzov sustav država smatra strukturnim i ahistorijskim, jer je zanemarena promjena odnosa među državama i povijesni kontekst, koji više nije isti kakav je bio kad se sustav razvijao (Agnew, Corbridge 1995).

Robert Keohane bavi se idealističkim poimanjem države i međunarodnih odnosa, te svijet poima kao jedinstven sustav u kojem djeluje jedinstvena kapitalistička ekonomija. Ne pridaje veći značaj državama, nego pravilima, normama, principima te obrascima donošenja odluka koji upravljaju globalnom ekonomijom. Država ostaje središnji akter, ali je njeno 
samostalno djelovanje bitno ograničeno i potiče ju se na suradnju. Kao i Waltz, Keohane operira s zatvorenim i apstraktnim sustavom i pozitivističkim pristupom međunarodnim odnosima. Odvaja međudržavno od unutardržavnog, što zahtijeva uniformnije poimanje teritorijalnih država kao glavnih aktera međunarodnih odnosa.

Nakon svršetka hladnog rata i dezintegracije hladnoratovskog poretka dolazi do redefiniranja položaja i uloge države u novom svjetskom poretku. Uvjeti u kojima se razvija suvremeni svijet i suvremeni poredak postavljaju pred geopolitičare neka pitanja: Kakva treba biti uloga suvremene države u globalnom geopolitičkom sustavu i geopolitičkim odnosima? Da li je suvremena država pogodna da bude osnovni oblik teritorijalne organizacije u suvremenom svijetu koji je sve više obilježen globalizacijom proizvodnje, potrošnje, trgovine i politike, širenjem tehnologije, izuma, inovacija i informacija? Da li je suvremena država sposobna odgovoriti na velik broj novonastalih izazova i prijetnji sigurnosti građana i stabilnosti društva koje se danas javljaju ponajviše zbog promjene geopolitičkih odnosa u svijetu? Da li je država sposobna učinkovito odgovoriti na pojavu globalnih problema koji ne poznaju državne granice, kao što su ekološke katastrofe, glad, zarazne bolesti, eksplozija stanovništva u svjetskoj periferiji, globalno zagrijavanje, zagađivanje zraka, voda, mora i tla? Ovo su pitanja na koja je vrlo teško odgovoriti. Njihova važnost i aktualnost ne dopušta stanovnicima ovog planeta da se ne pozabave njihovim rješavanjem, u sadašnjosti i budućnosti.

Joseph S. Nye također smatra da država gubi svoje nekadašnje značajke, a razlozi tome su višestruki. Decentralizacija državne kontrole odvija se u nekoliko pravaca. Difuzija državnih aktivnosti odvija se u pravcu privatnog, javnog i nevladinog sektora. Difuzija se također odvija na subnacionalnoj, nacionalnoj i supranacionalnoj razini. Decentralizacija i suradnja među državama nužne su i zbog novih prijetnji i nove prirode nacionalne sigurnosti koja je sve manje vezana samo uz države (Nye 2002).

Kriza suvremene države i sustava bez središnje vlasti evidentna je. Očituje se u više problema i prijetnji (koje možemo smatrati dijelovima uvjeta u kojima se razvija novi svjetski geopolitički poredak) čiji se opseg i snaga neprestano uvećavaju. Uloga države kao aktera u novom svjetskom poretku slabi. Pitanje je kako riješiti probleme koje države ne mogu riješiti samostalno, a koji su sve značajniji. Stoga se pred nas postavljaju pitanja fundamentalnog značenja: Da li je moguće riješiti probleme suvremenog svijeta bez mijenjanja značajki suvremenih država? Ako nije, da li je moguće promijeniti državu i međunarodni sustav da mogu odgovarati na suvremene izazove i probleme? Ako jest, treba početi s promjenama. Ako nije, da li je potrebna potpuna promjena osnovnog oblika teritorijalno-političke organizacije i svjetskog sustava?

Organizacija globalnog prostora u budućnosti ovisi o državama. Države će još dugo vremena ostati primarni oblik političke organizacije prostora i najvažniji akteri geopolitičkog poretka. Možemo očekivati daljnju proliferaciju država i integraciju u naddržavne cjeline.

Jedna od značajki suvremenog poretka je rast broja i jačanje uloge teritorijalnopolitičkih jedinice različitih od države, koje svoje postojanje zahvaljuju specifičnostima historijsko-geografskog procesa stvaranja i razvoja političke karte svijeta. Države su stvorene kao odvojeni dijelovi prostora, ali ne zauzimaju sve kopno na Zemlji. Ostale 
teritorijalno-političke jedinice su nepravilne političke jedinice i pseudodržave, koje se razlikuju po svom nastanku, razvoju i značajkama. Nepravilne političke jedinice dijele se na: teritorije pod vojnom okupacijom (turski dio Cipra, Golanska visoravan), teritorije u prijelaznom statusu (podijeljene države - Njemačka, Vijetnam, Koreja; druge teritorijalno-političke jedinice - Tajvan, Vatikan, Monako; kolonije i protektorati - Puerto Rico, Cookovo otočje, Grenland, Farski otoci), teritorije neizvjesnog statusa (Zapadna Sahara, Antarktika), teritorije pod stranom upravom (nekadašnji kondominiji, neutralne zone) i međunarodne teritorije (mandati i skrbništva) (Glassner 1995). Nepravilne političke jedinice su ostatak kolonijalnog doba, vojne okupacije, podjele ili nepostojanja želje da se na nekom prostoru organizira politička organizacija u obliku države.

Pseudodržave se od nepravilnih političkih jedinica razlikuju po načinu nastanka i po tome da nemaju priznat suverenitet i pravni subjektivitet. Nepravilne političke jedinice prethode pseudodržavama, imaju prijelazan ili neizvjesan status koji može završiti uspostavom nove države ili vraćanjem pod suverenitet druge države. Pseudodržave predstavljaju nastavak organizacije prostora nakon što je na njemu postojala država i degeneracija su državne organizacije prostora. Njihov status je nepriznat i neriješen. I po tome se razlikuju od nepravilnih političkih jedinica.

Pseudodržave nastaju dekonstrukcijom geopolitičkog poretka, dok novi poredak još nije u potpunosti uspostavljen u svim dijelovima prostora. Nastaju i zbog globalizacije, koja dovodi do slabljenja državne kontrole nad društvom i nekim dijelovima državnog teritorija. Pseudodržave najviše nastaju tamo gdje je došlo do radikalne promjene ili raspada starog izvjesnog sistema i stvaranja novih nesigurnih ili nestabilnih sistema. Geografski gledano, pseudodržave su najviše nastale u prostoru Rimlanda, gdje su bile posljedica etničkih sukoba koji su izbili raspadom komunističkih federacija, SSSR-a i SFRJ. Većina ovih pseudodržava nastala je kao izraz želje neke etničke skupine da teritorijalizira svoje postojanje, koristeći pritom nestabilnost novonastalih država, koje su suočene s problemom izgradnje državne strukture i prijetnjama svom opstanku i teritorijalnom integritetu.

Preliminarna klasifikacija pseudodržava podijelila je pseudodržave s obzirom na nastanak i funkcije. Razlikuju se institucionalizirane pseudodržave (Transdnjestarska Moldovska Republika, Abhazija, Nagorno-Karabah) i neinstitucionalizirane političke jedinice (dijelimo ih na prostore sukoba unutar neke države koji nisu pod kontrolom nijedne sukobljene strane - Zapadna Sahara, dijelovi nekih afričkih država, te na prostore koje kontroliraju terorističke ili kriminalne skupine - dijelovi Kolumbije, Burme itd.) (Cvrtila 2000). Pseudodržave su jedna od posljedica raspada ili dekonstrukcije geopolitičkog poretka hladnog rata kojim je narušena kontrola i hijerarhijska organizacija globalnog prostora. Najveći gubitak kontrole zbio se u starim (Bliski istok) i novim shatterbeltima (jugoistočna Europa, Podsaharska Afrika, središnja Azija).

Međunarodne organizacije su akteri svjetskog poretka neteritorijalnog karaktera, ali su im članice teritorijalnog karaktera. Postale su akteri svjetskog poretka znatno poslije država, a veće značenje dobivaju nakon II. svjetskog rata. Najznačajnija međunarodna organizacija je Organizacija ujedinjenih naroda (OUN). Međunarodne organizacije se dijele na međunarodne vladine i nevladine organizacije. S povezivanjem ekonomske, političke i sigurnosne sfere sve je teže napraviti potpuno jednoznačnu podjelu međunarodnih vladinih 
organizacija. Po obuhvatu ih dijelimo na univerzalne i regionalne, a po karakteru na ekonomske, političke i vojno-političke. ${ }^{5} \mathrm{~S}$ daljnjim razvojem suvremenog poretka može se očekivati njihov daljnji razvoj. Nevladine organizacije okupljaju različite članice, ali ne i države. Težište je na djelovanju nacionalnih grupa ili udruženja, a manje na pojedincima. Mogu biti organizacije političkih stranaka različitih država, međunarodne humanitarne organizacije, profesionalne organizacije, interesne skupine itd.

Jačanju uloge međunarodnih organizacija pogoduje slabljenje država, znanstvenotehnološka revolucija, proces globalizacije, dekonstrukcija hladnoratovskog poretka, pojava globalnih problema i globalnih izazova sigurnosti. Značenje im daje i sama njihova brojnost, jer danas u međunarodnim odnosima djeluju tisuće organizacija. Tradicionalna geopolitika o međunarodnim organizacijama nije vodila računa, ali nova geopolitika ih smatra akterima geopolitičkih odnosa (uz države, ostale teritorijalno-političke jedinice, nacije i pokrete). Time se približila znanosti o međunarodnim odnosima, koja ih smatra subjektima međunarodnih odnosa. Novo shvaćanje je sukladno s postmodernim shvaćanjem geopolitike, geopolitičkih odnosa i svijeta kao okoline u kojoj se zbivaju geopolitički odnosi. ${ }^{6}$

Ostali akteri novog svjetskog geopolitičkog poretka neteritorijalnog karaktera su pokreti, nacije i crkva. Pokreti, koji mogu ili ne moraju imati organizirane oblike djelovanja u institucionalnom smislu, danas imaju sve veću snagu. Postoje međunarodni pokreti političkog, humanitarnog, ekološkog karaktera. No danas je sve teže razlikovati karakter nekih pokreta, jer imaju više osobina, a gotovo svi su i politički (npr. Greenpeace je ekološki pokret, ali je također i politički). Mogućnosti djelovanja su im različite u različitim dijelovima svijeta. Procesi koji pomažu djelovanje pokreta su informatička i komunikacijska revolucija, globalizacija, slabljenje državne kontrole i širenje nekih vrsta demokracije na nove dijelove globalnog prostora. Nacije danas također imaju veliku važnost u geopolitičkim odnosima, ali ne toliku kakvu su imale u procesu formiranja nacionalnih država u prošlosti. Njihovo značenje umanjuju procesi koji pomažu djelovanje pokreta. Nacije su dobile ponovnu veliku važnost prilikom geopolitičke tranzicije i nastanka novih država, koje su počele tražiti i stvarati svoj novi identitet, sada temeljen ne samo na etničkom nego i na političkom principu. Isto vrijedi i za crkvu, čije je značenje sve manje. Najveće značenje od svih crkava ima katolička crkva, jer ima političko središte, visok stupanj organizacije i jedinstvenosti, te zbog velikog broja i teritorijalnog rasprostiranja katolika u svijetu.

\section{PROCESI U NOVOM SVJETSKOM GEOPOLITIČKOM PORETKU}

Istraživanje novog svjetskog geopolitičkog poretka ne bi bilo potpuno bez procesa koji se zbivaju u suvremenom poretku. Proučavanje procesa kao što su globalizacija, deteritorijalizacija kapitala, proizvodnje i potrošnje, promjene organizacije globalnog prostora, promjene u karakteru i shvaćanju sigurnosti, može nam ukazati na moguće pravce razvoja suvremenih odnosa u svijetu.

Najvažniji proces koji se zbiva u suvremenom poretku je proces globalizacije. Proces globalizacije je toliko široko poiman, sveobuhvatan, sveprisutan i akcelerativan 
da postoje mišljenja kako je proces globalizacije danas proces svih procesa, jedinstveni proces koji uključuje sve ostale procese koji obilježuju suvremeni poredak i suvremene geopolitičke i međunarodne odnose. Međutim, proces političke, ekonomske, kulturne globalizacije može se smatrati i jednim, najvažnijim među procesima koji se zbivaju u suvremenom poretku. Proces globalizacije danas je uzeo tolikog maha da postaje jedna od najdominantnijih odrednica suvremenog svijeta. Uz promjene struktura novog svjetskog geopolitičkog poretka i promjene geopolitičkih odnosa, globalizacija presudno utječe na pravce i intenzitet razvoja geopolitičkog poretka u svijetu.

Proturječnosti oko globalizacije očituju se čak i u tome da ne postoji ni približno jedinstvena i prihvaćena definicija globalizacije. Globalizacija je danas model razvoja koji više nije stvar izbora, već predstavlja stvarnost suvremenih odnosa. Renato Ruggiero smatra da globalizacija implicira "rast, razvoj i mirne, na suradnji osnovane, međunarodne odnose". Ideologija globalizacije ideologija je bogatih i visokorazvijenih država, prvenstveno SAD-a (Vukadinović 1999). Globalizacija se najčešce odnosi na cirkulaciju ljudi, roba, kapitala, usluga, ideja, vrijednosti, sve manje ograničenih na određeni geografski prostor i uobičajeno djelovanje. U pojmu globalizacija uključen je vrlo velik broj različitih aktivnosti, pa je stvaranje jedinstvenog koncepta ili jednoznačnog određenja globalizacije otežano.

Globalizacija se može poimati kao proces mijenjanja interesa i brige čovječanstva prema teritorijalnosti i tradicionalnom uređenju sustava država. Globalizacija nije stanje ili novi sustav koji bi trebao zamijeniti sustav država, ne odnosi se na vrijednosti ili strukturu, nego se odnosi na slijed koji se dešava u našim razmišljanjima i ponašanju. Globalizacija je proces koji se širi u različitim smjerovima preko nacionalnih granica i sposoban je doprijeti do svih zajednica bez obzira na geografski prostor, a nastaje u trenutku kad različiti ljudi i organizacije pokušavaju ostvariti svoje svakodnevne ciljeve i zadatke. Izvori globalizacije javljaju se u ekonomskim, političkim, tehnološkim, psihiloškim i socijalnim zbivanjima koja potiču širenje interesa i običaja preko ustaljenih granica. Globalizacija sa sobom donosi čitav niz globalnih fenomena, ruši ustaljeni koncept teritorijalnosti (dovodi do deteritorijalizacije), prevladava granice i vezu identiteta i teritorija, premješta važne aktivnosti izvan državnih ili nacionalnih granica. ${ }^{7}$ Globalizacija presudno utječe na geopolitiku kroz utjecaj na teritorijalnost, koja je uz moć središnji pojam u geopolitici. Globalizacija bi mogla dovesti do nestanka teritorijalnosti i moći države, te stvoriti neteritorijalan svijet bez granica. Globalizacija se može definirati i kao proces povezivanja i stvaranja međuovisnosti među teritorijima, te kao proces proširivanja i produbljivanja društvenih odnosa i institucija u prostoru i vremenu. Izraz je procesa kompresije prostora i vremena (Newman, Kliot 1999).

Zbog učinka procesa globalizacije i promjena u globalnom geopolitičkom sustavu, suvremeni poredak potrebno je istraživati kroz postmodernu i postrealističku paradigmu. Globalizacija se povezuje s nastankom mreža moći i suvereniteta koji se prekrivaju. Stvara se novi oblik hegemonije bez hegemona, koji se naziva transnacionalni liberalizam. Hegemonija je to ideologije tržišta, koja je danas dominantna u svijetu, a globalizacija je proces kojim se provodi ideologija tržišta i pristupa svim tržištima. Dva najveća geopolitička utjecaja globalizacije odnose se na promjene hijerarhijske organizacije prostora, koje se očituju u stvaranju novih transnacionalnih zajednica koje poništavaju stara određenja 
“mi-oni”. Očituju se i u stvaranju osjećaja povezanosti između međusobno udaljenih ljudi (Agnew, Corbridge 1995).

Deteritorijalizacija je proces koji je nastao kao posljedica procesa globalizacije. Deteritorijalizacija, kao proces prevladavanja teritorijalnosti i njenih ograničenja, prvo je zahvatila tržišta kapitala i utjecala na prostornu praksu i predstavljanja prostora. Globalizacija proizvodnje, financija, informatičkih i komunikacijskih tehnologija dovodi do sve manje vezanosti tih aktivnosti za određeni teritorij. Deteritorijalizacija je usko povezana s globalizacijom. Oba procesa su nezaustavljivi. Nezaustavljivost globalizacije omogućuje podrška političkih i ekonomskih elita razvijenih i moćnih država. Globalizacija na geopolitički poredak utječe geopolitičkim implikacijama, najviše kroz deteritorijalizaciju.

Deteritorijalizacija i stvaranje paralelnog svijeta u obliku cyberspace značajno su odredili kraj 20. i početak 21. stoljeća. Deteritorijalizacija je naziv za preuređivanje i prestrukturiranje prostornih odnosa kao posljedice tehnoloških, materijalnih i geopolitičkih transformacija krajem 20. stoljeća. Ujedno je i ime dano problematici teritorija koji gubi moć i značenje u svakodnevnom životu. Deteritorijalizacija danas označuje općenito rastavljanje kompleksa geografije, moći i identiteta, koji je navodno određivao i ograničavao život razvijenog svijeta u 20. stoljeću. Deteritorijalizacija se odnosi na nove uvjete u komunikaciji i informatizaciji, transgresiji naslijeđenih granica, prevladavanju podjela i nastanku jače globaliziranog svijeta (O' Tuathail 1999).

Najbolji primjer političkog djelovanja u pravcu deteritorijalizacije je geoekonomska vanjskopolitička strategija Clintonove administracije. ${ }^{8}$

Promjena organizacije i poimanja prostora vidi se kroz promjene koje su odgovor na suvremene geopolitičke uvjete i procese globalizacije i deteritorijalizacije. Danas se javljaju predviđanja koja čak govore o zamjeni tradicionalnog prostora cyberspaceom, no to ne može biti istina jer je svjetska politika podijeljena na velika područja u kojima vladaju borbe za teritorij, iznova naglašujući značenje geopolitike. No, na najvišoj razini globalnog sustava, globalizacija i nove tehnologije stvaraju nove tipove suradnje i ulogu geografije čine sve manjom. Za države koje sudjeluju u globalizaciji, teritorij je postao manje važan u priličnoj mjeri jer je uloga cyberspacea porasla zbog trenutačne mogućnosti komuniciranja, globalnih medija i mogućnosti velikih prebacivanja velikih količina novca trenutačno. Međutim, ostaje važnost tradicionalnog geografskog prostora. U budućnosti, borba će se voditi između država i korporacija za kontrolu cybespacea. U međunarodnom sustavu ostati će tenzije između globalizacije i fragmentacije, suradnje i sukoba, noviteta i tradicije (Spiegel 2000).

Važnost i osobine mjesta (place) i prostora (space) promijenili su se od razdoblja hladnog rata. Prostor je izgubio na značenju od svršetka hladnog rata, što je proces koji je počeo i prije, s kompresijom prostora i vremena. Lokacija ili mjesto dobilo je na važnosti ono što je izgubilo između 1947. i 1989. g. U hladnom ratu su usmjerenost na uzajamno nuklearno uništenje i izravni odnosi velesila uspjeli potisnuti lokaciju iz geopolitičkih odnosa. Geografski prostor bio je reduciran na jednostavnu euklidsku udaljenost na površini Zemlje, ili je sukladno tezi Nicholasa Spykmana poiman kao sveprisutan i nepromjenjiv. Razlikovanje lokacije i prostora ključno je. Prostor teži jednoobraznosti, lokacija singularnosti. Prostor se povezuje s apstraktnošću, slobodom, kretanjem, formalnošću. Lokacija se 
povezuje s poznatošću, sigurnošću, domom, povijesnom tradicijom, društveno-kulturnim odnosima, kontekstom i geografsko-sociološkim učincima. Taylor čak kaže da je proučavanje odnosa i tenzija između prostora i lokacije ključna zadaća političke geografije. Kompleksniji pristup primjereniji je realnostima suvremenog svijeta (regionalni sukobi, regionalizam, fragmentacija, transgranični izazovi sigurnosti, lokalizacija, globalizacija) (O’ Loughlin 2000).

Sigurnost u suvremenom svijetu i sigurnost koja bi trebala biti osnovni cilj svakog poretka, čini jedan od najvažnijih aspekata koji treba istraživati kako bi se razumio suvremeni poredak. Suvremeni svijet karakterizira pojava i rast različitih vrsta rizika, prijetnji i izazova sigurnosti. Prijelaz iz hladnog rata u posthladnoratovsko razdoblje obilježile su brojne turbulentne promjene u svijetu. Bio je to i prijelaz iz razdoblja velikog suparništva supersila na globalnoj razini, u razdoblje manjih sukoba regionalnog i etničkog karaktera. Bitno je smanjena mogućnost globalnog vojnog sučeljavanja. Suvremeno razdoblje označuje globalna hegemonija jedine preostale supersile, SAD-a, regionalni poretci u pojedinim dijelovima svijeta, te atomizirane države, nestabilnost i nesigurnost u ostalim dijelovima svijeta. Sigurnost je, suprotno predviđanjima s kraja hladnog rata, zadržala svoje značenje u međunarodnim odnosima i u velikom broju država. Međutim, promijenile su se značajke i shvaćanje sigurnosti. Stanje sigurnosti je s padom komunizma u istočnoj Europi is početkom raspada SSSR-a nakratko poboljšano. No, ubrzo je pogoršano na regionalnoj razini u jugoistočnoj Europi, istočnoj Europi i na Kavkazu, tj. u središtu svjetske kopnene mase i prostoru ključnom za sigurnost dijela Europe, Rusije i dijela Azije. Ovi događaji zbivali su se paralelno sa spoznavanjem potrebe da koncept sigurnosti treba dobiti šire značenje. Svršetak hladnog rata je pružio priliku da se shvati složenost i povezanost problema. Nesigurnost, koja se javila raspadom sustava globalnog sučeljavanja, postavlja problem za strukture poretka, koje moraju identificirati nove prijetnje i nalaziti nove odgovore u nacionalnoj i međunarodnoj sigurnosnoj politici. Na sigurnost utječu kriza i promjene suvremene nacionalne države pod utjecajem procesa globalizacije, deteritorijalizacije i znanstveno-tehnološke revolucije. Izazovi sigurnosti u novom svjetskom poretku bitno se razlikuju od izazova u hladnoratovskom geopolitičkom poretku. Umjesto tradicionalnih vojnih prijetnji, danas su izazovi uglavnom druge prirode. Izazovi sigurnosti u suvremenom svijetu ponajviše su nove neteritorijalne, transnacionalne prijetnje, koje se šire neovisno o državnim granicama. ${ }^{9}$ Takvi su izazovi terorizam, proliferacija oružja masovnog uništenja, bolesti, ekološke katastrofe, globalno zagrijavanje. Prijelaz s tradicionalnih na nove izazove i prijetnje sigurnosti, je i prijelaz s hard security prema soft security.

S krajem hladnog rata došlo je do promjena geopolitičkih odnosa, obilježja i teritorijalne demarkacije država i političkog predstavništva za politiku i sigurnost. Danas se događa i promjena u djelovanju prema rizicima koji su transnacionalni, pa se više ne može govoriti ni o tom da je sigurnosna politika i politika općenito stvar hijerarhijski organiziranih država. Na rizike se više ne može odgovarati kroz hijerarhijske političke intervencije. Politika utječe jedino na percepciju pojedinih rizika u društvu (Albert 2000). 


\section{ZAKLJUČAK}

Pitanje svjetskog poretka ključno je za budućnost Zemlje. Oko tog pitanja spore se i na njega pokušavaju utjecati brojni i iznimno jaki interesi aktera svjetskog poretka. Poretkom kao objektom istraživanja geopolitika se bavi koristeći vlastiti framework, te naglašavajući i istražujući fenomene koji su joj zanimljivi. Geopolitika naglašuje geografske faktore i povezuje ih s političkim faktorima.

Novi svjetski geopolitički poredak danas je realnost s kojom se moraju suočiti svi akteri geopolitičkih odnosa, ali i stanovnici planeta Zemlje, na čiji život utječe poredak u kojem žive. Novi svjetski geopolitički poredak, kao posljednji u nizu svjetskih poredaka, bitno se razlikuje od prijašnjeg svjetskog poretka hladnog rata. Svjetski poredak suvremenog doba stvoren je pod utjecajem više različitih faktora, ponajprije pod utjecajem geopolitičke tranzicije, koja je uslijedila nakon raspada hladnoratovskog geopolitičkog poretka. Prvi ključan moment u tranziciji raspad je jednog pola bipolarnosti na čelu s SSSR-om, a drugi moment je ubrzanje i produbljivanje procesa globalizacije, praćeno deteritorijalizacijom i novim poimanjem prostora. Uz globalizaciju javljaju se i lokalizacija i fragmentacija. Najvažniji akteri poretka i dalje ostaju države, ali je njihova uloga danas drukčija i manje važna nego što je bila prije, što je posljedica uvjeta koji vladaju u novom svjetskom poretku. Međunarodne organizacije sve više dobivaju na značenju, te danas jače utječu na procese u poretku nego države. Najvažniji proces u suvremenom poretku je globalizacija, koju čak smatraju procesom svih suvremenih procesa. Proces globalizacije praćen je procesima deteritorijalizacije, nove organizacije prostora i procesom evolucije sigurnosti (promjena od hard security prema soft security, sigurnost u globaliziranom svijetu). Suvremeni svjetski poredak i dalje prolazi kroz fazu svog nastanka i sazrijevanja, pa je teško govoriti o budućnosti. Možemo predvidjeti da će biti ispunjena rizicima i nesigurnostima novog tipa, te da će doći do prestrukturiranja i promjena značajki aktera kao odgovor na djelovanje drugih aktera i djelovanje akcelerativnih procesa.

\section{POZIVNE BILJEŠKE}

1. O hladnom ratu kao pojavnom obliku bipolarnog tipa međunarodnih odnosa više u: Vukadinović, R. (1998.), Međunarodni politički odnosi, Barbat, Zagreb, str. 229-236

2. Američka vanjska politika počiva na zaštiti i promociji američkih interesa u svijetu koji se mogu podijeliti na: vitalne interese, značajne nacionalne interese te humanitarne i druge interese. Prema: Vukadinović, R. (1999.), Globalizacija i globalna američka politika, Politička misao, vol. XXXVI, br. 1, str. 26-41

3. Više o geoekonomiji u: Čehulić. L. (2000.), Demokracija i ljudska prava u posthladnoratovskoj američkoj i europskoj politici, Politička misao, vol. XXXVII, br. 2, str. 109-122

Plevnik, J. (2001.), Značenje geopolitike i geoekonomije u suvremenim međunarodnim odnosima, Međunarodne studije, vol. I, br. 2-3, str. 21-42

4. Više u: Waltz, K. N. (2001.), Man, the State, and War, Columbia University Press, New York Waltz, K. N. (1979.), Theory of International Politics, McGraw-Hill Higher Education, New York

5. Više u: Vukadinović, R. (1998.), Međunarodni politički odnosi, Barbat, Zagreb, str. 106-107 
6. Opširnije izlaganje o međunarodnim organizacijama daleko prelazi opseg i svrhu ovog rada. Stoga je ovdje spomenuto samo najosnovnije o međunarodnim organizacijama.

7. Više u: Jurišić, K. (1999.), Globalizacija i ljudska prava, Politička misao, vol. XXXVI, br. 1, str. 70-82

8. Više o Clintonovoj vanjskopolitičkoj strategiji i geoekonomiji u: Čehulić, L. (2001.), Clinton i novi svjetski poredak, Politička kultura, Zagreb

9. Više u: Čehulić, L. (2002.), Transnacionalni izazovi američkoj politici, Međunarodne studije, vol. II, br. 1-2, str. 37-52

\section{LITERATURA}

Agnew J., Corbridge S., 1995: Mastering Space. Hegemony, territory and international political economy., Routledge, London

Albert M., 2000: From Defending Borders towards Managing Geographical Risks? Security in a Globalised World, Geopolitics, vol. V, br. 1, str. 57-80

Buzan B., 1990: People, States and Fear, Lynne Riener Publishers, Boulder, Colorado

Cvrtila V., 2000: Dekonstrukcija geopolitičkog poretka na primjeru pseudodržava, Politička misao, vol. XXXVII, br. 2, str. $85-88$

Čehulić L., 2000: Demokracija i ljudska prava u posthladnoratovskoj američkoj i europskoj politici, Politička misao, vol. XXXVII, br. 2, str. 109-122

Čehulić L., 2001: Clinton i novi svjetski poredak, Politička kultura, Zagreb

Čehulić L., 2002: Transnacionalni izazovi američkoj politici, Međunarodne studije, vol. II, br. 1-2, str. 37-52

Glassner M. I., 1995: Political Geography, Wiley \& Sons, New York

Huntington S. P., 1996: The Clash of Civilizations and the Remaking of World Order, Simon \& Schuster, New York, 1996.

Jurišić K., 1999: Globalizacija i ljudska prava, Politička misao, vol. XXXVI, br. 1, str. 70-82

Newman D., Kliot N., 1999: Globalisation and the Changing World Political Map, Geopolitics, vol. IV, br. 1-2, str. 1-16

Nye J. S., 2002: The Paradox of American Power, Oxford University Press, New York

O’ Loughlin, J., 2000.: Geography as Space and Geography as Place: The Divide Between Political Science and Political Geography Continues, Geopolitics, vol. V, br. 3, str. 126-137

O' Tuathail G., 1999: Borderless Worlds? Problematising Discourses of Deterritorialisation, Geopolitics, vol. IV, br. 1-2, str. 139-152

Plevnik J., Značenje geopolitike i geoekonomije u međunarodnim odnosima, Međunarodne studije, vol. I, br. 2-3, 2001., str. 21-42

Spiegel S. L., 2000: Traditional Space vs. Cyberspace: The Changing Role of Geography in Current International Politics, Geopolitics, vol. V, br. 3, str. 114-125

Taylor P. J., 1993: Political Geography. World Economy, Nation-State and Locality, Longman Scientific \& Technical, Essex

Vukadinović R., 1998: Međunarodni politički odnosi, Barbat, Zagreb

Vukadinović R., 1999: Globalizacija i globalna američka politika, Politička misao, vol. XXXVI, br. 1, , str. 26-41 
SUMMARY

\title{
New World Geopolitical Order: Theoretical Determinants
}

\author{
Petar Kurečić
}

Geopolitical world order represents one of geopolitical cathegories. Geopolitical order can be defined in a couple of ways. It is understood as a condition of geopolitical relations in global geopolitical system and as a concept for explaining these relations. This is how geopolitical order is defined by Taylor. Agnew and Corbridge define it as a set of rules, institutions, activities, strategies through which international political economy functions. The key of this concept is a differentiation among spatial practice, representation of space and representational space. Geopolitical order is related to the political economy of spatial practice or hierarchical organisation of space. Geopolitical discourse is related to the geopolitical perception of the hierarchical organisation of space, which has in its centre interpretation of that space, which does not need to be correct and doesn't have to fulfill. Geopolitics studies world order from its aspects and according to its needs, using its specific framework. Deconstruction of the Cold War geopolitical world order, followed by geopolitical transition, established a New geopolitical world order. The key moment was deconstruction of the USSR and Eastern bloc, which had left the United States as the biggest centre of power in the World without a real adversary. In order to understand the nature and characteristics of the contemporary, New geopolitical world order, we must learn the determinants of an order in general, conditions of development, players and processes in the New geopolitical world order. The post Cold War world and global geopolitical system are undergoing transformations. Players and processes in the geopolitical order have remained almost the same, after the last geopolitical transition. The position and power of players has changed, as well as the character and intensity of the processes in the New World Order. Interactive engagement of players and processes has changed global geopolitical relations. Conditions of development of the New World Order can be divided into five fields: political field, field of security, economic field, social field, scientific and technological field. Contemporary order has been developing in the age of World time, which is a period when all geopolitical and cultural consequences of the Post Cold War era are connected with acceleration of economic, social and cultural globalisation. Players are crucially determining order, and they also strongly affect the processes. States are the most important players in the order, and they are undergoing big transformation. Traditional role of the state is now changing. What remains the same is interdependence as the key determinant of a geopolitical system, which is not any more just a system of territorial states. Realism and Neorealism are the perspectives adressing the questions of a state's role in a system of states. Other players in a geopolitical order are international organisations, international movements, nations, churches. Processes in the New World Order are globalisation, deterritorialisation, changes in organisation and perception of space, as well as changes in nature and perception of security. Globalisation is the most important process today, which can be perceived as a process of change of 
interest of the mankind towards territoriality and traditional arrangement of a system of states. Globalisation is also followed by localisation and fragmentation. Deterritorialisation is a process of the overcoming of territoriality and its limits. It is closely connected with globalisation. Both processes are unstoppable. Changing of perception of space is mainly tied with new relations between space, which is losing its importance, and place, which is gaining importance. The nature of security is also changing in accordance with new risks, threats and challenges to security. New threats and challenges are changing hard security to soft security (i. e. security in a globalised World). The processes are most strongly affected by international organisations, not states. However, processes sometimes evolve almost independently. Players and processes interact and create global geopolitical relations. Questions of characteristics and relations within the New World Order are decisive for the future of the World. New geopolitical World Order is a reality which all players in a geopolitical World order must face. New World Order is still undergoing through the phase of its creation and maturation. Therefore, the future of the world order is still uncertain. We can predict that it will be a future full of new risks, new uncertainties and insecurities. We can also predict that the restructuring and changing of the players will continue, as a reaction to the actions of other players and accelerating processes.

Petar Kurečić, mr. sc. profesor geografije i diplomirani politolog Antuna Strbana 18, 10000 Zagreb, Hrvatska/Croatia, e-mail: petar.kurecic@zg.htnet.hr 